\title{
Central Nervous System Teratoma with Malignant Transformation
}

National Cancer Institute

\section{Source}

National Cancer Institute. Central Nervous System Teratoma with Malignant

Transformation. NCI Thesaurus. Code C7015.

A central nervous system teratoma characterized by the presence of a malignant component. The malignant component most often is sarcomatous

(rhabdomyosarcoma or undifferentiated sarcoma) or carcinomatous (squamous cell carcinoma or adenocarcinoma). 